Miami Nature Biotechnology Short Reports

TheScientificWorld (2001) 1 (S3), 90SR

ISSN 1532-2246; DOI 10.1100/tsw.2001.196

\title{
SIGNALING THROUGH THE DEATH RECEPTOR CD95 (APO-1/FAS)
}

\author{
Marcus E. Peter \\ Ben May Institute for Cancer Research, University of Chicago \\ MPeter@ben-may.bsd.uchicago.edu.
}

INTRODUCTION AND METHOD. Using classical immunoprecipitation protocols in combination with high-resolution 2D gels, we identified a complex of proteins that formed around the death domain of the stimulated death receptor CD95 (APO-1/Fas) receptor which we called the death-inducing signaling complex (DISC)(1). We went on to characterize the three major components of the DISC: First, the adaptor FADD/Mort1 was identified (1) then caspase-8 and the caspase-8-like apoptosis inhibitor c-FLIP were cloned (2,3). Formation of the DISC upon apoptosis induction results in activation of caspase-8 by proteolytical cleavage into the prodomain containing two death effector domains (DED) and two active subunits, p18 and p10 (4). Thus, caspase-8 plays an essential role in the execution of death receptor-mediated apoptosis. To determine the localization of endogenous caspase-8 we used a panel of subunitspecific anti-caspase-8 monoclonal antibodies in confocal immunofluorescence microscopy.

RESULTS. In human breast carcinoma cells MCF7 caspase-8 predominantly colocalized with and bound to mitochondria. After induction of apoptosis through CD95 or TNF receptor I, active caspase- 8 translocated to plectin, a major crosslinking protein (cytolinker) of the three main cytoplasmic filament systems. Plectin was quantitatively cleaved early by caspase-8 in all cells tested during death receptor and drug induced apoptosis. In primary fibroblasts from plectin deficient mice apoptosis induced reorganization of the actin cytoskeleton, as seen in wild type cells, was severely impaired suggesting that during apoptosis plectin is required for the reorganization of the microfilament system (5). Mitochondria play an important role in many form of cell death. All of the apoptogenic activities of mitochondria can be blocked by overexpression of $\mathrm{Bcl}-2$ or $\mathrm{Bcl}-\mathrm{x}_{\mathrm{L}}$. In certain cell types most of caspase- 8 is activated downstream of mitochondria (6). In these Type II cells overexpression of Bcl-2 or Bcl- $\mathrm{x}_{\mathrm{L}}$ can inhibit apoptosis, and cleavage of caspase-3 and 8. In Type I cells, however, caspase-8 is mainly activated by the DISC and seems to directly activate caspase-3. CD95-mediated apoptosis in Type I cells cannot be inhibited by overexpression of $\mathrm{Bcl}-2$ or Bcl- $\mathrm{X}_{\mathrm{L}}$. Thus, we have identified two independent cell types that either do or do not use mitochondria for execution of apoptosis.

DISCUSSION. We have shown that human peripheral $\mathrm{T}$ cells that are resistant to CD95 mediated apoptosis are Type II cells which differentiate into apoptosis sensitive Type I cells after prolonged incubation with interleukin-2. Recently, we have focused at a novel function of mitochondria during CD95 mediated apoptosis. We found that expression of $\mathrm{Bcl}-2 / \mathrm{Bcl}-\mathrm{x}_{\mathrm{L}}$ gives mitochondria the activity to sequester active caspase- 8 thus preventing the execution of apoptosis despite activation of caspase- 8 at the DISC. The data suggest that active caspase- 8 binds to the mitochondrial protein BAR (7) on the surface of mitochondria. Thus, we have 
identified a novel mechanism of regulation of caspase-8 activity that might be relevant for regulation of apoptosis and cell proliferation.

\section{REFERENCES.}

1. Kischkel, F.C., Hellbardt, S., Behrmann, I., Germer, M., Pawlita, M., Krammer, P.H., and Peter, M.E. (1995) EMBO J. 14, 5579-5588

2. Muzio, M., Chinnaiyan, A.M., Kischkel, F.C., O' Rourke, K., Shevchenko, A., Scaffidi, C., Zhang, M., Ni, J., Gentz, R., Mann, M., Krammer, P.H., Peter, M.E., and Dixit, V.M. (1996) Cell 85, 817-827

3. Scaffidi, C., Schmitz, I., Krammer, P.H., and Peter, M.E. (1999) J. Biol. Chem. 274, 15411548

4. Medema, J.P., Scaffidi, C., Kischkel, F.C., Shevchenko, A., Mann, M., Krammer, P.H., and Peter, M.E. (1997) EMBO J. 16, 2794-2804

5. Stegh, A.H., Herrmann, H., Lampel, S., Weisenberger, D., Andrä, K., Seper, M., Wiche, G., Krammer, P.H., and Peter, M.E. (2000) Mol. Cell. Biol. 20, 5665-5679

6. Scaffidi, C., Fulda, S., Srinivasan, A., Li, Feng, Friesen, C., Tomasseli, K.J., Debatin, K.M., Krammer, P.H., and Peter, M.E. (1998) EMBO J. 17, 1675-1687

7. Zhang, H., Qunli, X., Krajewski, S., Krajewska, M., Xie, Z., Fuess, S., Kitada, S., Pawowski, K., Godzik, A., and Reed, J.C. (2000) Proc. Natl. Acad. Sci. U S A 97, 25972602 

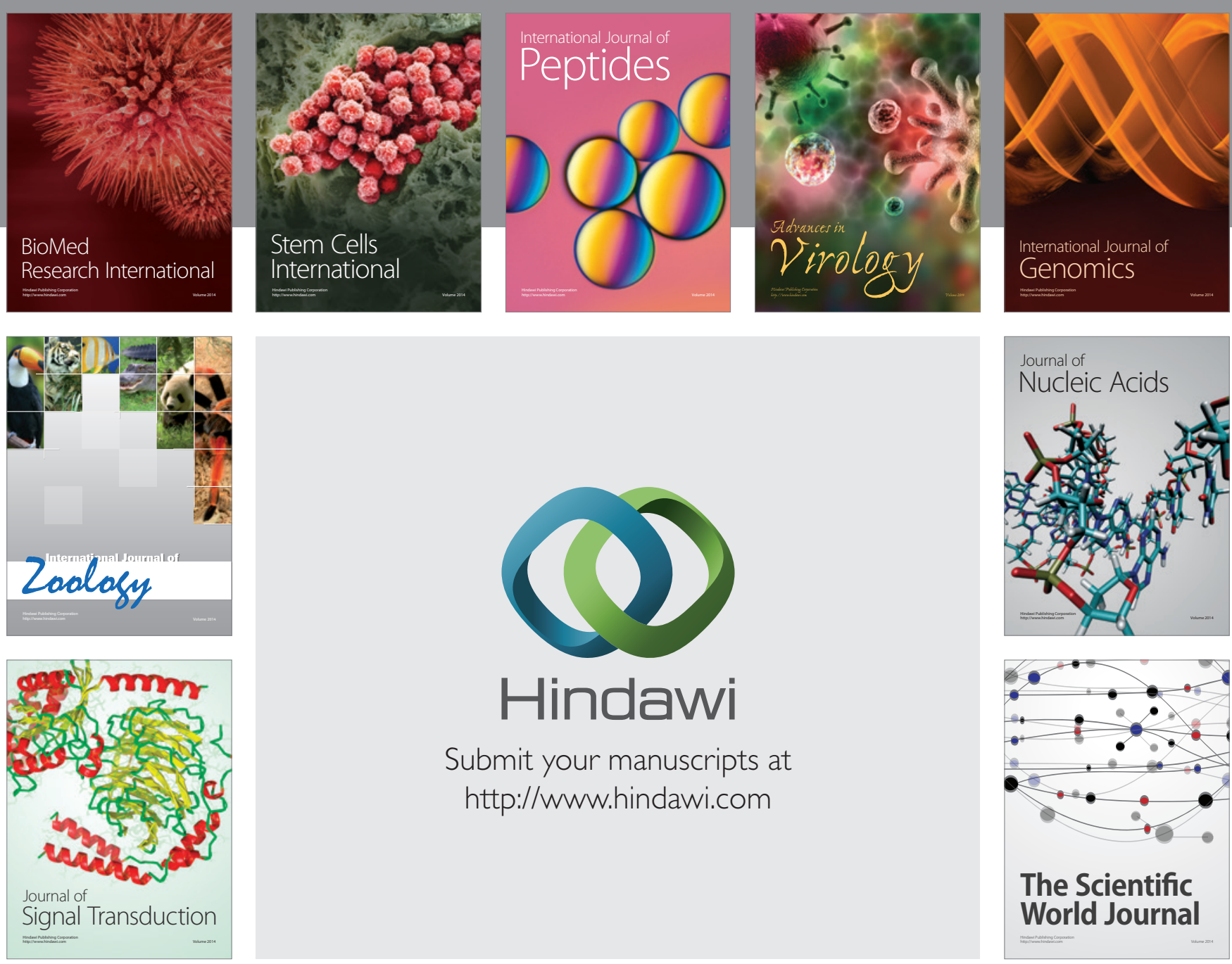

Submit your manuscripts at

http://www.hindawi.com
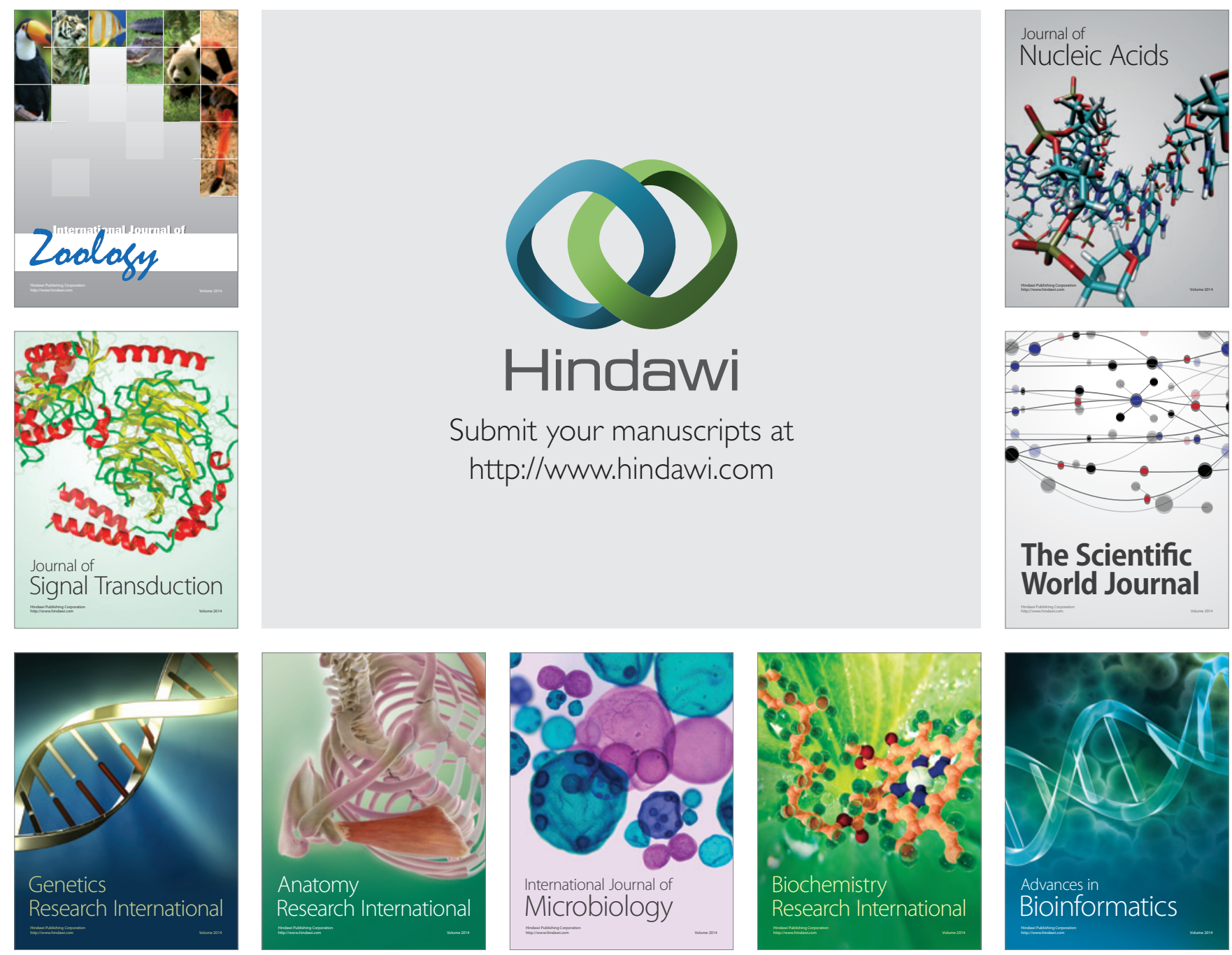

The Scientific World Journal
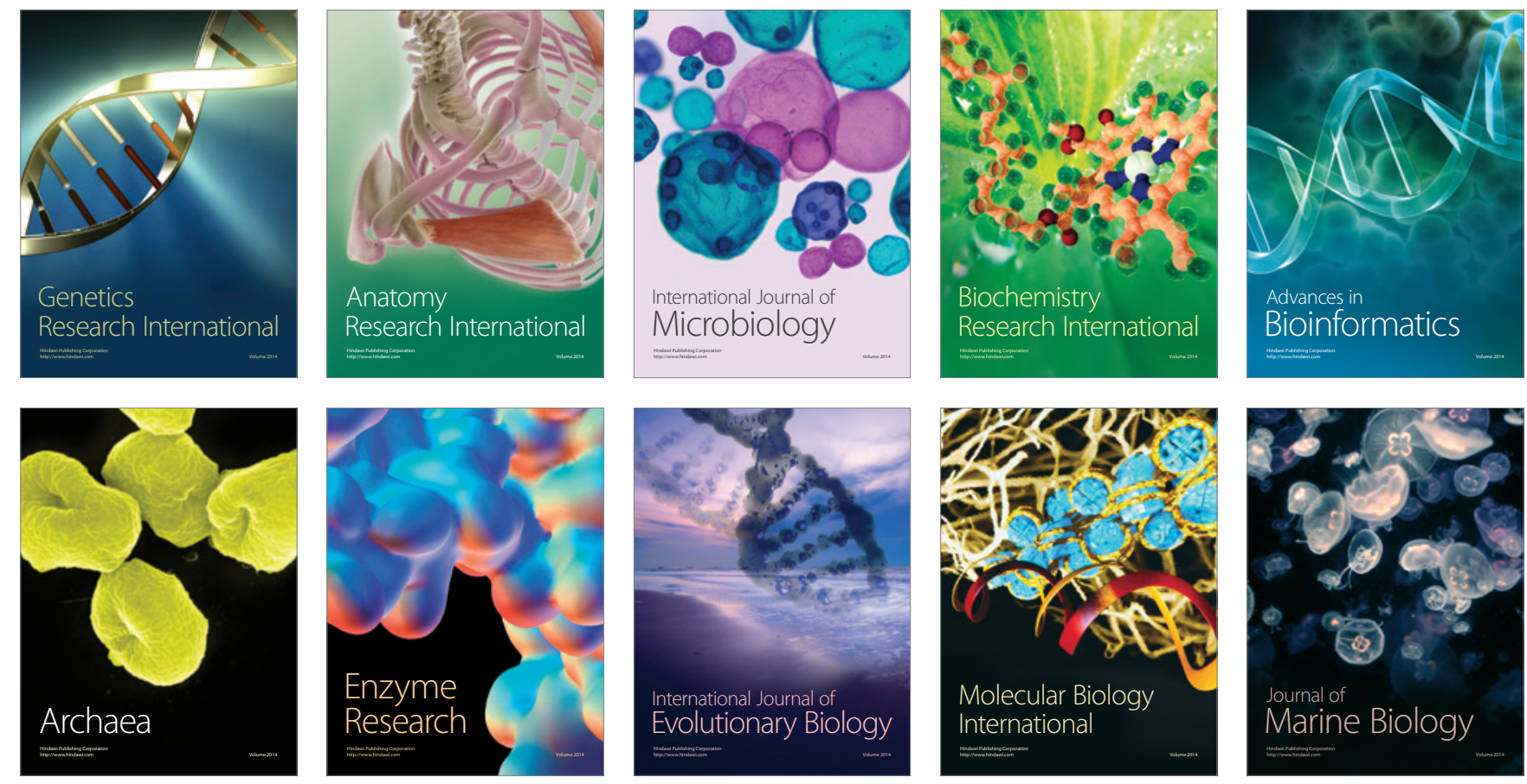